\section{EI Límite a la Protección de las Tierras Indígenas de la Ley 19.253}

\section{María del Rosario Salamanca Huenchullän'.}

\begin{abstract}
The law 19.253 intended to introduce a legislative variant sustained in the return of a historical debt of the Chilean State to the indigenous, a context which establishes the protection of their lands as an exigency of the national interest. This land is seen as threatened and trampleed by the same State and their organizations, through the public works construction. developing for them a discourse legitimate sustained in a western vision that does not give effective and real content to the multiculturality:
\end{abstract}

This work approaches the topic of the indigenous lands, that as an exigency of the national interest introduces in the Chilean legislation the Indigenous Law 19.253, in their relationship to the expropriation for the public works that, by virtue of public usefulness, are built on these same lands.

From a legal point of view, is realized an analysis of the Political Constitution of the Republic, and the legal bodies that govern the expropriation, in relationship to the Indigenous Law 19.253. as well as, realices an exposition of the facts that gave cause for the constitutional accusation against the ex Public Works Minister for the affectation of indigenous lands by expropriation for the construction the Coastal Highway and the Faja Maizan in the 9th region.

Finally: it is analyzed how to facem the affectation of their territory and ignorance of their rights, increasingly the indigenous develop claim and defense strategies of their territories, emerging each time from in this process with greater clarity of the need for acceptance of multiculturality, and a new relationship more just. democratic and with solidary between the State and the Indigenous Peoples of Chile.

\section{RESUMEN}

La ley 19.253 pretendió introducir una variante legislativa sustentada en la devolución de una deuda histórica del Estado Chileno a los indigenas, contexto en el que establece la protección de sus tierras como una exigencia del interés nacional. Estas se ven amenazadas y atropelladas por el mismo Estado y sus organismos, a través de la construcción de obras puiblicas, desarrollando para ello un discurso legítimante sustentado en una visión occidental que no da efectiva y real cabida a la multiculturalidad.
Este trabajo aborda el tema del límite a la protección de las tierras indígenas, que como una exigencia del interés nacional introduce en la legislación chilena la Ley Indigena 19.253 , en su relación con la expropiación para la construcción de obras publicas, que en virtud de la utilidad publica se construyen sobre estas mismas tierras.

Desde un punto de vista jurídico, se realiza un análisis de la Constitución Política de la República, y los cuerpos legales que rigen en general la expropiación, en su relación con la Ley Indigena 19253, asi como, realiza una exposición de los hechos que dieron lugar a la acusación constitucional en contra del ex Ministro de Obras Públicas por la afectación de tierras indigenas via expropiación para la constracción de la Carretera de la Costa y la Faja Maizán en la IX Región.

Finalmente, se analiza cómo frente a la afectación de su territorio y desconocimiento de sus derechos. crecientemente los indigenas desarrollan estrategias de reclamación y defensa de sus territorios, surgiendo en este proceso cada vez con mayor claridad la necesidad de la aceptación de la multiculturalidad. y una mueva relación más justa, democrática y solidaria entre el Estado y los Pueblos Indigenas de Chile.

\section{INTRODUCCION}

La polémica entre el Estado y los pueblos indigenas en torno a la ocupación del territorio de parte del primero y la defensa del mismo por los segundos, pone a la sociedad chilena en su conjunto frente a un tema aún no resuelto, que dice relación con la aceptación de la multiculturalidad y la efectiva vigencia de los derechos humanos de los indigenas en Chile.

El Estado de Chile desde sus inicios se ha caracterizado por la negación de la existencia de los indigenas. situación que tiene profundas raices en la forma misma del Estado, dada su construcción bajo el modelo de la tradición iluminista y el paradigma de que "todos somos iguales"-, el que obviamente no da lugar a la multiculturalidad.

Para los indigenas, el tema de fondo apunta a un debate que es mucho más profundo que la afectación actual de su territorio por la construcción de obras públicas, la construcción de represas hidroeléctricas, o la usurpación de las forestales. El cuestionamiento apunta a la histórica relación entre el Estado y los pueblos indigenas en la que el primero utiliza todo su poder para la ocupación definitiva del territorio indigena ${ }^{3}$, iniciada junto a su nacimiento mismo, y los segundos presentan una defensa histórica frente a este invasor que no ha respetado su cultura, sus tradiciones, su costumbre ni su forma de vida, ocupando su territorio dejándoles una parte infima de sus tierras, desconociendo su existencia estigmati-

\footnotetext{
I Asistente Social, Universidad de Chile yestudiante egresada de la Escuela de Derecho de la Universidad Catolica de Temuco.

2El articulo l" de La Constitución Chilena del año $19 x 0$ se inicia señalando "Los hombres nacen litres e iguales..." Conjumtamente con el prosecto de ler indigenu que el ejecutivo envio al legislativo en al aĩo 1993 se envio un provecto de reforma constiftucional que pretendia reconocer a los pueblas indigenas. que fue rechazado por el legislativo, reconociendo solanente la ley 19.253 las etnias indigenas que expresamente seriala en sur articulol inciso 20

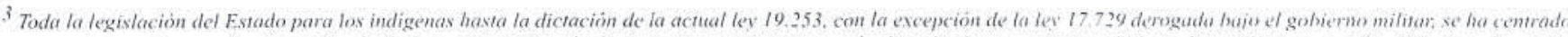

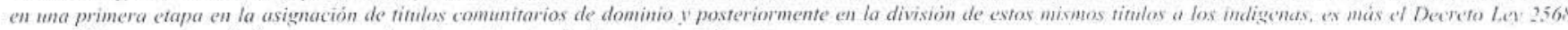
pretendic borrar a tratés de una norma legal la existencia de los mismos indigenas.
} 
zándolos, discriminándolos y ubicándolos en las categorías socioculturales y económicas más desposeidas, lucha que aún continúa y en la que han llevado siempre las de perder.

El término de la dictadura militar y la recuperación de la democracia fue interpretado por las organizaciones mapuche de la época como la llegada de un período especial de participación y búsqueda de soluciones a los problemas que enfrentaban como pueblo. En este sentido, la voluntad manifestada por el entonces candidato a la presidencia por la concertación Patricio Aylwin, por medio de la firma del llamado "acuerdo de Nueva Imperial" en el año 1989 les ofrecía la garantía del reconocimiento constitucional, la dictación de una nueva ley indigena y la creación de la Corporación Nacional de Desarrollo Indígena -CONADI-, aspectos estos dos últimos que consideraban la activa participación de los propios indígenas, lo que apuntaba hacia una nueva relación entre el Estado y los pueblos indigenas de Chile.

¿Qué pasó con todos estos acuerdos políticos entre el Estado y las organizaciones representativas del movimiento indigena de la época?. El reconocimiento constitucional de los pueblos indigenas hasta ahora no se ha hecho realidad. En cuanto a la nueva ley indigena, ésta es promulgada el año 1993 por el primer gobierno de la concertación con posterioridad a la dictadura, junto con ello también se crea la CONADI, sin embargo existe una falta de voluntad politica para hacer realidad la protección de las tierras indigenas y los principios que obligan al Estado y sus instituciones en el mismo sentido. Por otra parte el manejo que se hace de la CONADI desde las esferas de gobiemo, aparece contradictorio con lo proyectado en su creación y a las funciones que a este organismo le asigna la ley.

¿Cuál es el límite o hasta donde llega la protección de las tierras indigenas en la Ley 19.253?. La respuesta a esta interrogante nos lleva a enfrentar un tema de fondo subyacente en toda la legislación que el Estado ha dictado para los indigenas en Chile, esto es, la no aceptación de la multiculturalidad.

El presente trabajo sustenta la tesis de que más allá de la protección de las tierras indigenas establecida en la ley. el alcance de esta protección en nuestro país, es un problema político que pasa por un efectivo reconocimiento del Estado de Chile como un Estado multicultural y multiétnico.

Es frente a la posibilidad de expropiación de tierras indigenas donde el Estado y sus organismos, se ven enfrentados a dilucidar sus propios paradigmas, la respuesta que desde el Estado se da a la expropiabilidad o inexpropiabilidad de las tierras indigenas, conlleva elementos de valoración politica, económica, social y cultural. Una cosa es la declaración legal de la protección de las tierras indigenas en virtud del interés nacional y otra la forma en que se le da contenido y alcance a esta protección.

\section{La Expropiabilidad en el Marco Juridico}

La expropiación para la construcción de Obras Públi- cas, está regulada en el ordenamiento jurídico chileno por, la Constitución Política de la República, el Decreto Ley 2168 de 1978 que autoriza la Ley Orgánica del Procedimientr de Expropiaciones, y el Decreto con Fuerza de Ley 850 del 12 de Septiembre de 1997, publicado en el Diario Oficial el 25 de Febrero de 1998, Ley Orgánica del Ministerio de Obras Públicas, que es para el caso de la construcción de caminos la ley que autoriza la expropiación. En el caso de las tierras indígenas, concurre además a esta regulación la Ley indigena 19.253 de 1993.

La interpretación y análisis, de los cuerpos normativos señalados, conlleva un componente étnico muchas veces no considerado, y que sin embargo reviste gran importancia por las implicancias presentes y futuras para los pueblos indigenas de Chile. Los mapuche, esto es la "gente de la tierra". no existen como pueblo y como cultura, sin la existencia de la tierra y no de cualquier tierra sino de "su tierra".

El tratamiento de las tierras y el territorio indigena presenta múltiples variables, no reducibles sólo a su aspecto jurídico normativo, más aún. el derecho como fenómeno social tampoco lo es y aún dentro del mismo, la expropiación por causa de utilidad pública es solo una de sus instituciones.

El territorio desde el punto de vista indigena, contiene elementos propios de la cosmovisión, es esta forma particular de relación con la tierra, lo que hace al mapuche ser lo que es, y lo que lo diferencia de la cultura winca u occidental, de tal forma que tratar el tema indigena mapuche descontextualizando el territorio y su contenido de las personas adscritas a él. hacen que toda posible interpretación pierda el sentido y alcance. transformándose en una interpretación abstracta y absurda que no responde a los principios de equidad y justicia que el derecho debe realizar.

EL artículo $19 \mathrm{~N}^{\circ} 24$ de la Constitución, tras asegurar a todas las personas el derecho de propiedad sobre toda clase de bienes corporales e incorporales, reglamenta la única forma constitucionalmente reconocida de privar del dominio. que es la institución de la expropiación y señala que:

"Nadie puede en caso alguno ser privado de su propiedad del bien sobre el que recae o de alguno de los atributos o facultades esenciales del dominio, sino en virtud de una lev general o especial que autorice la expropiacion por causa de utilidad publica o de interés nacional. calificada por el legislador: El expropiado podrá reclamar de la legalidad del acto expropiatorio ante los tribunales ordinarios y tendrá siempre derecho a indemnización por el daño patrimonial efectivamente causado. la que se fijará de comin acuerdo o en sentencia dictada conforme a derecho por dichos tribunales.

A falta de acuerdo. la indemnización deberá ser pagada en dinero efectivo al contado.

La toma de posesión material del hien expropiado tendrá lugar previo pago del total de la indemnización. Ia que, a falta de acuerdo. será determinada provisionalmente por peritos en la forma que señale la ley: En caso de reclamo 
El constituyente es claro al señalar que sólo la ley puede autorizar al órgano administrativo a proceder a la expropiación misma, estableciendo la existencia de ésta como un supuesto indispensable y previo, de tal modo que no forma parte integrante del procedimiento expropiatorio propiamente tal.

La declaración de la utilidad pública o interés nacional son la únicas dos hipótesis reconocidas por el constituyente como suficientes para que opere la expropiación. Para calificar la existencia de estas causales, la potestad está en manos del legislador.

Los conceptos, utilidad pública e interés nacional, son parte de lo que el constituyente entendió por la función social de la propiedad, la que según disposición constitucional, "comprende cuanto exijan los intereses generales de la Nación, la seguridad nacional, la utilidad y la salubridad públicas y la conservación del patrimonio ambiental" (articulo19 $N^{\circ} 24$ CPR).

La función social de la propiedad es un concepto comprensivo de otros conceptos, además de la utilidad pública y el interés nacional. Sin embargo para los efectos de la expropiación, el constituyente solo previó la concurrencia de las dos determinadas expresiones de la función social que señala, por lo que toda otra restricción sería inconstitucional.

Los intereses generales de la Nación, constituyen un concepto de contenido abstracto que expresa un bien jurídico de orden superior, que involucra directamente a la Nación toda, entera, y jamás por importante que sea sólo un sector de ella. Se entiende por otra parte básicamente relacionado con el beneficio superior de la sociedad política globalmente considerada, como un todo, sin referencia alguna a categorias o grupos sociales, económicos o de cualquier orden.

La utilidad pública es también un bien jurídico de carácter abstracto que significa beneficio colectivo, sin embargo se le entiende referido especialmente al orden interior de la República.

Respecto de la reclamación de la legalidad del acto expropiatorio hay dos hipótesis a considerar, la primera la establece la propia Constitución, "el expropiado podrá reclamar de la legalidad del acto expropiatorio ante los tribunales ordinarios ". Esta disposición se refiere a la reclamación de la resolución que decreta la expropiación en virtud de la ley que autoriza a la autoridad administrativa para expropiar, es entonces una situación de nulidad de la expropiación. La segunda es la posibilidad que tienen los afectados por una ley de expropiabilidad de interponer un recurso de inaplicabilidad por inconstitucionalidad.

La nulidad de la expropiación constituye una nulidad de derecho público, ella está prevista expresamente en la Cons- titución en los casos de utilización irregular de las potestades públicas por parte de los órganos del Estado, toda vez que éstos tienen únicamente y de manera restrictiva, las atribuciones que de modo expreso le han conferido la Constitución y las leyes. De ello se deriva que cada vez que un órgano de la administración se extralimita en los márgenes de su competencia, el acto o resolución emitida esté afecto inevitablemente de nulidad, y este efecto jurídico sancionatorio es invariable, porque las competencias son de derecho estricto y no pueden presumirse, siendo además insaneable bajo cualquier circunstancia.

La expropiación se formaliza en una situación concreta por un acto administrativo que debe reunir determinados requisitos para ajustarse a derecho. Los que se rigen básicamente por los artículos 7, 1 inciso $4^{\circ}, 5$ inciso final y 6 , de la Constitución. En la nulidad de la expropiación, el juicio de reproche recaerá en el acto expropiatorio, puesto que sólo su dictación la realiza materialmente, mientras no se dicte el acto expropiatorio, ésta aún no existe, por lo que no podría configurarse la expropiación antijurídica. La nulidad siempre debe ser reclamada, ante esta reclamación, el tribunal requerido para ello, una vez constatada la existencia del vicio, está en el deber ineludible de pronunciarla.

El efecto jurídico ordinario de la declaración de la nulidad es, la eliminación de las consecuencias jurídicas derivadas del acto administrativo anulado, llevando las cosas al estado anterior de su ejecución, es decir. que para el caso de nulidad del acto administrativo que decreta la expropiación de tierras indigenas, este consistiria en que una vez anulado el acto administrativo que decretó la expropiación, la entidad expropiante si ya tomó posesión material del bien debería devolverlo y el expropiado si ya recibió todo o parte de la indemnización debería también devolverla, sin perjuicio de poder serle indemnizados los perjuicios causados.

Respecto de la inconstitucionalidad de la expropiación, la Corte Suprema ha dicho, "La calificación de utilidad publica o de interés social que haga una ley general o especial puede impugnarse por el recurso de inaplicabilidad. pues la Constitución no ha exigido de la ley expropiatoria la mera afirmación de la existencia de los requisitos de utilidad pública o de su interés social, sino el cumplimiento estricto de ellos y su formal declaración " (C. S., 8-11-1973, Revista Fallos del Mes $N^{\circ} 187$, página 84).

El recurso de inaplicabilidad por inconstitucionalidad de la ley está normado en el artículo 80 de la Constitución, en los siguientes términos: "La Corte Suprema, de oficio o a petición de parte en las materias de que conozca, o que le fueren sometidas en recurso interpuesto ante cualquier gestión que se siga ante otro tribunal, podrá declarar la inaplicable para esos casos particulares todo precepto legal contrario a la Constitución. Este recurso podrá deducirse en cualquier estado de la gestión, pudiendo ordenar la Corte la 
suspensión del procedimiento".

El objeto principal de la inaplicabilidad, es obtener la no aplicación de preceptos legales contrarios a la Constitución, que de aplicarse en la gestión causarian grave daño al recurrente, por lo que para deducir el recurso o formular la petición de inaplicabilidad es menester que la gestión se encuentre pendiente, es decir, que aún no se haya resuelto por sentencia ejecutoriada el asunto en que se pretende aplicar el precepto que se estima inconstitucional. Lo pueden interponer las personas que tienen derecho a intervenir en la gestión correspondiente como partes directas, terceros coadyuvantes o terceros interesados, y siempre que el precepto legal que se trata de aplicar les cause agravio.

Invariablemente la jurisprudencia de la Corte Suprema ha sostenido que, "El recurso de inaplicabilidad es de carácter meramente doctrinario, supuesto que no otorga al tribunal a quien compete su conocimiento más atribuciones que la de resolver; por el simple examen de los términos de una ley, si ella es o no contraria al texto del Estatuto Constitucional; es decir, el fallo que se dicta en el recurso no resuelve ninguna de las cuestiones que son materia de la controversia judicial en que él incide, y debe limitarse únicamente a decidir si la ley objetada de inconstitucionalidad puede o no considerarse vigente para tal efecto.

Basta pues, para promover este recurso, que exista la posibilidad. no la certeza, de que una ley inconstitucional pueda ser aplicada en la especie debatida, porque lo contrario llevaria a una revisión de las acciones y excepciones de fondo ahi debatidas. lo que desnaturalizaria su finalidad $y$ caracteristicas, que difieren sustancialmente de las que coresponden a otros recursos instituidos en los códigos procesales, sean ordinarios o extraordinarios". (Revista de Derecho y Jurisprudencia, tomo 52,II, I" , pp. 399 y 400, Corte Suprema, 15-12-1955).

Los efectos del recurso se limitan a declarar inaplicable para ese caso particular el precepto legal considerado contrario a la Constitución, por lo que en el caso en estudio si llegase a efectuarse una declaración de inaplicabilidad de una ley que autorice la expropiación de tierras indígenas, ello se traduciria en la inaplicabilidad del precepto legal para las tierras afectadas específicamente consideradas.

El otro derecho que la Constitución otorga al expropiado es, el derecho a una indemnización por el daño patrimonial efectivamente causado con la expropiación, de tal forma que para el caso en estudio, la indemnización es el resarcimiento del daño al patrimonio efectivamente causado con la construcción de una obra pública determinada sobre las tierras indígenas, lo que involucra el resarcimiento respecto de los danos al derecho de propiedad de las personas individualmente consideradas y el perjuicio a los derechos colectivos de las etnias indigenas, en los términos de la ley especial indigena.
La pregunta obvia que surge con relación al tema en estudio es ¿cuál es el daño efectivamente causado al patrimonio de los indígenas titulares del dominio de las tierras indígenas objeto de expropiación por la construcción de una obra pública?. Esta interrogante dado el contenido étnico del tema, que es precisamente el que hace diversa la interpretación normativa de esta institución para los indígenas, plantea diferentes problemas a resolver, entre ellos:

1. - ¿Cómo se indemnizaria el derecho de propiedad sobre el valor cultural y religioso de la tierra dentro de la cosmovisión indigena mapuche?

2. - ¿Cómo se indemnizaría a los indigenas el derecho de propiedad sobre los derechos colectivos que les otorga la ley?

3.- ¿Es posible compensar materialmente la afectación de los espacios territoriales considerados sagrados por la cultura mapuche tales como el rewe y los cementerios (eltum) donde reposan sus antepasados?

Toda vez que la Constitución remite a la ley la expropiación por causa de utilidad pública, habrá que ver si los cuerpos legales que concurren a regular esta materia, dan cuenta de la respuesta a estas interrogantes. Ello significa necesariamente atender al contenido del estatuto de tierras indígenas contemplado en la ley 19.253 de 1993, ya que si bien, nuestro ordenamiento parte del principio del libre ejercicio de la propiedad privada, las tierras indigenas regidas por esta ley especial precisamente por tener un contenido étnico reconocido y valorado por el legislador, están protegidas por el interés nacional y sujetas a ciertas limitaciones que hacen su tratamiento diverso al resto de las tierras de particulares no indigenas en el territorio nacional.

El artículo 13 de esta ley establece que: "Las tierras a que se refiere el articulo precedente (artículo 12 que señala cuales son las tierras indígenas), por exigirlo el interés nacional, gozarán de la protección de esta ley y no podrán ser enajenadas, embargadas, gravadas, ni adquiridas por prescripción, salvo entre comunidades o personas indigenas de una misma etnia".

El artículo 13 crea un nuevo estatuto juridico para la categoria especial de inmuebles que son las tierras indigenas, consagrando la protección de las mismas, por exigirlo el interés nacional. Para la construcción de las Obras Públicas en estas tierras se hace necesario traspasar su propiedad al Estado. Sin embargo ellas están protegidas por la ley indigena que es para estos efectos ley especial, de tal forma que la aplicación de cualquier normativa que afecte tierras indigenas se debe considerar el artículo citado. Ello es de fundamental importancia en la interpretación y análisis de los cuerpos normativos que concurren a regular el tema de las obras públicas en tierras indigenas. 
El contenido de la protección de las tierras indígenas, que es la norma general establecida, se refiere a cuatro instituciones específicas, ellas son: la enajenación, el embargo, el gravamen y la prescripción adquisitiva ${ }^{4}$.

Respecto del sentido y alcance a que alude la enajenación, de la historia del establecimiento de la ley es posible deducir que los legisladores al utilizar este vocablo hacian referencia a los títulos traslaticios de dominio, esto es: a la venta, la dación en pago, la donación y los aportes en sociedad, que importaran que el dominio quedase fuera del mercado especial de las tierras indígenas circunscrito a los indígenas de la misma etnia.

"Como primer principio básico, se plantea el reconocimiento y protección de las tierras pertenecientes a las comunidades. Se pretende evitar su libre acceso al mercado. salvo en lo relativo a incorporar un concepto especial, innovador, que podria denominarse "mercado de tierras indigenas", en tanto sólo entre éstos se concibe la posibilidad de comercializar, enajenar o transar". Senador Navarrete (Historia de la Ley 19.253, Biblioteca del Congreso Nacional, Pp: 1484, año 1997).

Al declarar el legislador la inembargabilidad, la prohibición de gravámenes y de prescripción adquisitiva de las tierras indigenas refuerza la idea de que no pueden ser enajenadas. La misma norma establece algunas excepciones a la norma general, esto es, situaciones en que pueden realizarse este tipo de actos, bajo circunstancias y con requisitos específicos.

El legislador impone además restricciones a los atributos del dominio: "Igualmente las tierras cuyos titulares sean Comunidades Indigenas no podrán ser arrendadas, dadas en comodato, ni cedidas a terceros en uso, goce o administración.

Las de personas naturales indigenas podrán serlo por un plazo no superior a cinco años".

Esta disposición obedece a la intención de evitar abusos y evitar que la ley sea burlada, así quedó establecido en las discusiones parlamentarias. "Muchas veces hemos visto que se arrienda por 99 años y, en muchas ocasiones, como consecuencia de la mala intención, los indigenas finalmente son despojados de sus tierras. Con esta norma se subsana el punto y nadie podría en lo sucesivo, arrendar por más de cinco años". Diputado Garcia (op. cit.pp. 3716).

La única excepción establecida a la prohibición de enajenar las tierras indígenas la constituye la permuta especial por tierras no indigenas, la que es aplicable sólo a las tierras indigenas pertenecientes en propiedad a las personas naturales indigenas. "Para el objeto de dejar claramente establecido que sólo las tierras de personas naturales indigenas podrán ser permutadas, la Comisión (...) acordó intercalar en el inciso tercero después de la expresión "en todo caso". la palabra "éstas" (op. cit. pp. 1332).

Si se atiene a la historia fidedigna de la tramitación de la ley, puede señalarse que el fundamento de la permuta especial indigena, se encuentra en el beneficio del propietario indigena, "Esta disposición permite al indigena que posea cuatro hectáreas de terreno en los alrededores de Temuco, donde se quiere construir una población, venderlas con autorización de la CONADI, y con su producto adquirir un predio en otro lado, a lo mejor, de 100 o 120 hectáreas ". Diputado García (op. cit.pp. 3716).

Aparecen como requisitos propios de la permuta de tierras indigenas establecida en esta ley, en primer lugar, que vaya en beneficio del permutante y, en segundo lugar, que sea solicitada ante la Corporación directamente por el propietario indigena interesado.

Las normas de protección de las tierras indígenas analizadas, son imperativas, de tal forma que la sanción a su contravención de acuerdo a las normas generales es la nulidad absoluta. Sin embargo el legislador quiso dejar aún más claridad sobre ello al establecer expresamente la sanción en los siguientes términos: "Los actos y contratos celebrados en contravención a este articulo adolecerán de mulidad absoluta".

La protección de las tierras indígenas establecida por el legislador de la Ley 19.253, obedece a tres ideas centrales básicas, en primer lugar al reconocimiento de la existencia de las etnias indigenas en el contexto de la sociedad nacional ${ }^{5}$, luego y como corolario de lo anterior al reconocimiento de su estrecha relación con la tierra como fundamento de su existencia y cultura, y finalmente a su valoración como parte integrante de las raíces de la nación Chilena, es de estas ideas argumentativas fundacionales de donde deviene la declaración del interés nacional involucrado en su protección.

De la argumentación desarrollada en torno al tema, da cuenta la discusión parlamentaria consignada en la historia de la ley:

"Las denominadas "leyes indigenas" que el Estado Chileno ha dictado a lo largo de su historia, por lo general han tenido como objetivo asimilar a los pueblos indigenas. Erróneamente, se ha considerado un valor positivo para la sociedad global la supuesta homogeneidad cultural, educacional, lingüistica y racial de los pueblos autóctonos. Las leyes han sido más instrumentos de asimilación y perdida de identidad indigena que de desarrollo y progreso".

"El espiritu de esta iniciativa es absolutamente diferente. Establece la diversidad de las culturas existentes en la sociedad chilena, fomentando su desarrollo y reconociendo por tanto, el carácter propio de los pueblos indigenas y el derecho que les asiste a desarrollarse, segun sus propios criterios, culturas y costumbres".

\footnotetext{
${ }^{4}$ Un análisis exegético pormenorizado de cada una de estas instituciones, aparece en el articulo del abogado Jaime López Allendes "Kas Tierras ludigenas en la Le'. $19.2 .5,3$. en este volumen.

5 Si bien junto al proyecto de la lev indigena en análisis también se envio al legislativo un provecto de reforma de la Constituciön que daha lugar al reconocimiento constitucional de los pueblos indigenas, éste no prospero y los pueblos indigenas solo son reconocidos en el texto de la actual ley indigena como ctuias.
} 
"Las leves anteriores han legislado, principalmente, en torno al concepto de tierras indigenas. En cambio, la nueva legislación se fundamenta en las personas, tanto en las que viven en las áreas rurales como en las que habitan en las ciudades". Diputado Huenchumilla. Presidente de la Comisión Especial de Pueblos indigenas. (op. cit. pp. 3.697 y 3698).

“Por primera vez en la historia de nuestro pais se propone una ley que reconoce no solo la existencia, sino el derecho a desarrollarse, a partir de sus propias identidades culturales a las etnias que conforman nuestra nacionalidad. Por primera vez, también, no sólo se reconocen oficialmente. sino que el Estado valora y se obliga a proteger; preservar y fomentar el desarrollo de nuestras culturas autóctonas".

"De modo que esta normativa es un avance sustancial en la construcción y perfilamiento de nuestra propia identidad nacional, pues sólo ahora se empieza a reconocer que somos una sociedad pluricultural, expresando en derecho una realidad sociológica, históricamente ignorada $y$ omitida ${ }^{*}$

"Este proyecto también constituye, por cierto, un serio intento de empezar a respetar; al menos en parte, una gran demanda histórica, una historia de dominación, de usurpación, de exterminio, de ahusos, de marginación, de menosprecio, de injusticia, de subordinación politica, juridica, ideológica y cultural". Diputado Jara. (op. cit. pp. 3.708).

"En nuestro pais los pueblos indigenas constituyen uno de los sectores más pohres y postergados. Históricamente sufrieron injusticias y atropellos, tanto en la época de la Colonia como en el Chile republicano, aplicándoseles medidas politicas y legislativas que les imponian una cultura $y$ una forma de vida distinta, privándoles paulatinamente de un elemento fundamental de su vida: la tierra". Diputado Kuzmicic. (op. cit.pp. 3.720 y 3.721 ).

"Un pais moderno debe reconocer las diversas culturas que hay en su interior: porque enriquecen a la sociedad, a la nación y a la cultura nacional, por lo que la legislación debe salvaguardar a estos pueblos, que son los primigenios de Chile, los originarios, las raices de muestra sociedad".

"El proyecto de ley en estudio. que es un cuerpo legal armónico, estructural y democrático. plasmado por un consenso de todos los miembros de la comisión, recoge estos principios sobre la base de los postulados de discriminación positiva en favor de los indigenas, acogidos por las más modernas legislaciones en el derecho comparado y en el derecho internacional".
"Este respeto a su cultura implica un sistema justo de tenencia de la tierra, con certeza de poder traspasarla a sus descendientes (...)".

"El olvido, la postergación y el desprecio hacia estos pueblos les ha originado un daño histórico. por lo que pagamos una deuda histórica con esta ley". Diputado Ojeda. (op. cit. pp. 3.730 y 3.731 ).

La fundamentación señalada se traduce en el artículo $1^{\circ}$ de la ley en los siguientes términos:

"El Estado reconoce que los indigenas de Chile son los descendientes de las agrupaciones humanas que existen en el territorio nacional desde tiempos precolombinos, que conservan manifestaciones étnicas y culturales propias siendo para ellos la tierra el fundamento principal de su existencia y cultura".

"El Estado reconoce como principales etnias indigenas de Chile a: la Mapuche, Aimara, Rapanui o Pascuenses, la de las comunidades Atacameñas, Quechuas y Collas del norte del pais, las comunidades Kawaskar o Alacalufe y Yămana o Yagán de los canales australes. El Estado valora su existencia por ser parte esencial de las raices de la nación Chilena, asi como su integridad y desarrollo, de acuerdo a sus costumbres y valores".

"Es deber de la sociedad en general y del Estado en particular; a través de sus instituciones respetar; proteger $y$ promover el desarrollo de los indigenas, sus culturas, familias y comunidades, adoptando las medidas adecuadas para tales fines y proteger las tierras indigenas, velar por su adecuada explotación, por su equilibrio ecológico y propender a su ampliación".

La Ley 19253 rompe el esquema existente anteriormente en la legislación indigena en que sólo se trataba el tema de la tierra separándolo de lo que eran los indigenas y el significado que ésta tiene para ellos. A diferencia de leyes anteriores, esta ley establece principios generales de protección desarrollo y fomento de los indigenas; establece la calidad de indigena y protege las tierras indigenas por exigirlo el interés nacional.

La discusión del tema realizada por el legislativo da cuenta de la clara visión que se tuvo de la necesidad de enfrentar la existencia de los pueblos indígenas al interior de la nación chilena, como un tema de Estado, en ella el Estado de Chile se obliga a respetar, proteger y promover el desarrollo de los indigenas, en base argumentaciones que dan cuenta de la discriminación y el atropello de sus derechos fundamentales de que éstos han sido objeto a través de la historia, de parte del mismo Estado y sus instituciones. Sin embargo, la aplicación que se da a las normas alli establecidas en la actualidad no es congruente ni con los principios señalados en la ley ni con 
la argumentación sobre la cual se encuentra estructurada.

Diferentes sectores político-económico interesados en adquirir tierras indigenas han señalado que la ley indigena, entraba la libre circulación de los bienes y que tendría algún grado de contradicción con las normas que regulan la propiedad en la Constitución de 1980, esto es, con el artículo $19 \mathrm{~N}^{\circ} 23$ y con el artículo $19 \mathrm{~N}^{\circ} 24$. Al respecto cabe destacar que, la Ley 19.253 no entra en contradicción con ninguno de estos preceptos puesto que la historia de la ley y el texto de la misma denotan claramente el cabal cumplimiento de los requisitos para su constitucionalidad.

El Artículo $19 \mathrm{~N}^{\circ} 23$ de la Constitución Política de la República, "Garantiza a todas las personas: La libertad para adquirir el dominio de toda clase de bienes, excepto aquellos que la naturaleza ha hecho comunes a todos los hombres o que deban pertenecer a la Nación toda y la ley lo declare asi. Lo anterior es sin perjuicio de lo prescrito en otros preceptos de esta Constitución.

Una ley de quórum calificado y cuando asi lo exija el interés nacional puede establecer limitaciones o requisitos para la adquisición del dominio de algunos bienes".

El artículo 19 en su número 24, "Garantiza a todas las personas: El derecho de propiedad en sus diversas especies sobre toda clase de bienes corporales e incorporales.

Sólo la ley puede establecer el modo de adquirir la propiedad, de usar; gozar y disponer de ella y las limitaciones y obligaciones que deriven de su función social. Esta comprende cuanto exijan los intereses generales de la $\mathrm{Na}$ ción, la seguridad nacional, la utilidad y la salubridad píblicas y la conservación del patrimonio ambiental ".

El Primer Informe de la Comisión Especial para el estudio de la legislación referida a los Pueblos Indígenas, sobre el proyecto de ley relativo a la protección, fomento y desarrollo de los Pueblos Indigenas señala:

"Son normas de quórum calificado del proyecto en informe, las siguientes: Artículos 12, 13, 15, 17 y 18. Estas disposiciones establecen limitaciones o requisitos para la adquisición del dominio de determinados bienes. Por ello, de acuerdo con lo que dispone el inciso final del $N^{\circ} 23$ del artículo 19 de la Constitución, en relación con el inciso tercero del artículo 63 del mismo cuerpo legal, necesitan para su aprobación o establecimiento de la mayoría absoluta de los diputados y senadores en ejercicio". (op. cit. pp. 3639). Ello se reiteró en los sucesivos tramites de la discusión de la ley, finalmente se deja constancia de que los artículos citados "quedan aprobados por unanimidad en la comisión". (Op cit. pp. 3586).
El artículo 13 de la Ley 19.253 junto con establecer esta nueva categoría de inmuebles que son las tierras indigenas, introduce limitaciones tanto a la libertad para adquirir toda clase de bienes como al ejercicio mismo del derecho de propiedad, ello en virtud de una ley de Quórum calificado puesto que todo el artículo 13 se votó como Quórum calificado y está fundamentando en el interés nacional, de tal forma que estas limitaciones son totalmente constitucionales.

La exigencia del interés nacional según consta en las actas de las discusiones parlamentarias, dice relación con la exigencia histórica de conservación de las tierras ancestrales indigenas como parte integrante de las raices de la Nación Chilena, que constituye también la idea fundamental del mensaje con que el ejecutivo envio al legislativo este proyecto de ley, la que se ve reflejada tanto en los principios de la ley como en otras de sus disposiciones, tales como:

El artículo $1^{\circ}$ inciso $2^{\circ}$, el Estado reconoce a las principales etnias indigenas de Chile respecto de las que señala que valora su existencia por ser parte esencial de las raices de la Nación Chilena.

El artículo $7^{\circ}$ inciso segundo por su parte expresa que el Estado tiene el deber de promover las culturas indigenas, las que forman parte del patrimonio de la Nación Chilena.

De tal forma que el interés nacional que el legislador invoca como una exigencia para las restricciones que consigna en el artículo 13, no está circunscrito sólo a los indigenas de Chile sino a toda la nación chilena entendida en su conjunto. El legislador extrapola los intereses de los indigenas para los que está legislando en forma especial a los intereses de toda la sociedad y lo hace en consideración a conceptos tan fundamentales como las raices y el patrimonio de la Nación".

El Decreto con Fuerza de Ley 850 invoca como fundamento de la expropiación la utilidad pública, pero la Ley 19.253 hace referencia a un concepto similar, el interés nacional, para proteger las tierras indigenas, ambos conceptos son parte de la función social de la propiedad reconocidos en el artículo $19 \mathrm{~N}^{\circ} 24$ de la Constitución. Se estima que, habiendo ya establecido el legislador el interés nacional para la protección de las tierras indigenas, no podria en virtud del mismo interés nacional autorizar su expropiación.

Sin perjuicio de lo anterior y como una forma de ir profundizando el análisis de la posibilidad de expropiación de las tierras indigenas, se considerará la posible aplicación de este Decreto con Fuerza de Ley cuyo artículo 105 señala: " $L a$ Fiscalia del Ministerio de Obras Públicas tendrá a su cargo la tramitación de las expropiaciones necesarias para la construcción de las obras publicas, como de aquellos a que se refiere el inciso $2^{\prime \prime}$ del articulo $2^{\prime q u e ~ s e ~ r e g i r a i n ~ p o r ~ e l ~ D e c r e-~}$

\footnotetext{
${ }^{6}$ El abogado Rodrigo Lillo en su articulo " La legislación como aspecto de la relación intercultural". señala textualmente que: "... precisamente exte fundamento let imterés nacional] es el que dota a la ley indigena de una posición privilegiada dentro del ordenamiento juridico... ". Articulo citado. pagina 7 parrafo 2". en este volumen. -
} 
to Lev 2.186 de 1978. Para éstos efectos se declaran de utilidad pública los bienes y terrenos necesarios para la ejecución de dichas obras ". El artículo 2 inciso $2^{\circ}$ extiende la facultad cuando el Ministerio actúa por mandato de otros entes públicos del Estado o municipalidades.

Los artículos 45 y sub siguientes, ubicados en el párrafo $V$ "De las expropiaciones Servidumbres $y$ Donaciones". declaran asimismo de utilidad pública los terrenos necesarios para la construcción de caminos, extracción de tierras, arenas y áridos, servidumbres de tránsito y acueducto.

De acuerdo a la normativa constitucional, este Decreto ley constituye la ley de expropiabilidad requerida como supuesto previo indispensable para proceder a la expropiación propiamente tal y en este sentido se lo ha utilizado para privar de su propiedad en general a los particulares por causa de utilidad pública, ello sin embargo sin hacer referencia a la actual Ley 19.253, la que por constituir ley especial para los indigenas que son aquí los sujetos de la expropiación además para las tierras indigenas que son el objeto de la expropiación, constituye ley especial por lo que prevalece sobre este Decreto con Fuerza de Ley.

Que el Decreto con Fuerza de Ley 850 constituya una ley de carácter general en el ámbito especifico de la expropiación, lo señala claramente el artículo 105, que declara de utilidad pública "los terrenos necesarios para la construcción de obras públicas " y los artículos 45 y sub siguientes que imponen una serie de limitaciones al dominio para los efectos de las expropiaciones también a "los terrenos necesarios para ello", las tierras indigenas constituyen una parte de lo que aqui el legislador llama los terrenos, cuyas características especiales fueron consideradas por el legislador de la Ley 19.253 para sustraerlas del régimen común y dictar en torno a ellas una normativa especial que impone limitaciones tanto al titular de la propiedad como al tercero que quiera enajenarlas, ello por exigirlo el interés nacional y en un artículo que dentro de esta ley se votó con Quórum calificado precisamente porque impone tales limitaciones.

El que la ley indigena sea ley especial, tanto en su aspecto material, esto es para las tierras indígenas, como en su aspecto personal, para las personas indigenas, queda claramente establecido en el artículo primero que sienta los principios de la misma, en el análisis de su articulado y en la argumentación en que se sustenta según la historia de la ley, de ahí que para los efectos de su aplicación en cualquier materia que afecte tierras indigenas, incluida la expropiación, es la ley que prevalece y tanto los particulares como los órganos del Estado están obligados a cumplir con lo preceptuado en esta norma especial.

Respecto del procedimiento para llevar a cabo la expropiación, el Decreto con Fuerza de Ley en análisis, se remite al Decreto Ley 2186 de 1978, que aprueba la Ley Orgánica del procedimiento de expropiaciones y que por lo demás establece en nuestro sistema un procedimiento único al que deberán ceñirse todas las expropiaciones por causa de utilidad pública o interés nacional, lo que queda claramente establecido en sus artículos $1^{\circ}$ y 41 que señalan:

Artículo $1^{\circ}$ : "Toda expropiación por causa de utilidad publica o de interés social o nacional. cualquiera que sea la ley que la autorice, o la institución que la decreta. se sujetará al procedimiento establecido en el presente texto".

Artículo 41: "Desde la fecha de vigencia de la presente ley, quedarán derogadas todas las leyes preexistentes sobre las materias que en ella se tratan, ain en la parte que no le sean contrarias".

A los efectos de determinar si el procedimiento establecido es o no aplicable a las tierras indigenas por la vía de este decreto, es necesario como supuesto previo la existencia de una ley de expropiabilidad que autorice la expropiación de tierras indigenas, la que de acuerdo al análisis anteriormente realizado no existe.

Sin perjuicio de lo anterior, se analizará si el procedimiento que establece este cuerpo legal podria - supuesta una ley anterior que autorice la expropiación de tierras indigenasser aplicable a las tierras indigenas. Este procedimiento expropiatorio consta de diversos actos que permiten llevar adelante la expropiación, los que pueden ubicar en tres momentos sucesivos en el tiempo, los procedimientos previos a la expropiación, el acto expropiatorio mismo y sus efectos, y el desistimiento de la expropiación el que cuando se presenta es posterior a la expropiación ya decretada, la autora se remitirá a analizar los dos primeros.

Como parte de los procedimientos previos, está la autorización para la autoridad competentemente autorizada para expropiar, de emitir una resolución que ordene el estudio de la expropiación de un bien determinado, en este caso determinadas tierras indigenas afectadas por el trazado de una obra pública proyectada. La resolución de dicho estudio, se publica en extracto en el Diario Oficial y se anota al margen de la inscripción de dominio del Conservador de Bienes Raíces respectivo, inscribiéndose además en el registro de interdicciones y prohibiciones de enajenar.

En el caso de las tierras indigenas, el Conservador de Bienes Raíces está obligado por disposición del artículo 15 de la ley 19.253 a enviar esta información al registro de tierras indigenas, por otra parte pudiera presentarse la situación de que el Conservador de Bienes Raices, considerando que esta inscripción entra en contradicción con el artículo 13 de la ley indigena que declara estas tierras protegidas por el interés nacional prohibiendo su enajenación y gravámenes, se negase a inscribir dicha autorización.

Según el Decreto Ley, todo el procedimiento expropiatorio se iniciará y continuará con el nombramiento de 
una comisión de tres miembros, que determinará el monto provisional de la indemnización, señalando expresamente que es la entidad expropiante la que designará los miembros de esta comisión de entre los técnicos de diversas especialidades que figuran en una lista de peritos aprobada por el Presidente de la República por decreto del Ministerio de Hacienda.

El artículo 39 de la Ley 19.253 crea la CONADI como: "el organismo encargado de promover; coordinar y ejecutar: en su caso, la acción del estado en favor del desarrollo integral de las personas y comunidades indigenas, especialmente en lo económico, social y cultural y de impulsar su participación en la vida nacional". Respecto del tema de las tierras indigenas, sus funciones especificas son las siguientes:

"Asumir cuando asi se le solicite, la defensa juridica de los indigenas y sus comunidades en conflictos sobre tierras y aguas y ejercer las funciones de conciliación y arbitraje de acuerdo a lo establecido en esta ley

"Velar por la protección de las tierras indigenas" a través de los mecanismos que establece esta ley".

"Promover la adecuada explotación de las tierras indigenas y velar por su equilibrio ecológico".

Los preceptos de la ley indigena obligan a la Corporación a intervenir en el procedimiento de expropiación de tierras indigenas "en favor de los indigenas".

El articulo 34 otorga a los indigenas el derecho a participación en asuntos de su interés, ello forma parte de los derechos colectivos de los indigenas, los que deben ser considerados como parte del procedimiento, puesto que es obvio que la eventualidad de una expropiación de sus tierras es una materia de injerencia o relación con cuestiones indigenas, y especialmente lo es para el interés de los afectados.

Todo lo anteriormente señalado constituye un momento previo al acto expropiatorio propiamente tal por lo que en él no existe aun expropiación. La expropiación se concreta con el acto administrativo que la dispone, existiendo al respecto dos posibles alternativas: que el Presidente de la República disponga por Decreto Supremo, o si corresponde a una entidad pública desconcentrada o descentralizada, se haga mediante resolución de ésta, previo acuerdo adoptado en conformidad a las normas legales por las que se rija, constituyendo para todos los efectos legales, tal Decreto Supremo o resolución el "acto expropiatorio".

Los articulos $7^{\circ}$ y $8^{\circ}$ regulan lo relativo a las publicaciones en el Diario Oficial, el diario o periódico de la provincia en que se ubica el bien expropiado y la entrega por Carabineros de Chile de una copia del extracto, asi como la fecha de producción de efectos del acto expropiatorio.

${ }_{7}^{7}$ El subrayado es de la autora. ${ }^{8}$ La normativa señalada. exige una actitud de protección activa de parte del Estado y sus
en cualquier conflicto solbre tierras en que estén involucrados indigenas.
El artículo $9^{\circ}$ regula la posibilidad de reclamación del acto expropiatorio de parte del expropiado, el que tiene un plazo para realizarlos que es de 30 dias desde la publicación en el Diario Oficial del acto expropiatorio, pasados los cuales sin que haya presentado reclamo se extingue definitivamente el derecho a formularlo. Las hipótesis ante las cuales puede reclamar son las siguientes:

a.- Que se deje sin efecto la expropiación por ser improcedente en razón de la inexpropiabilidad, ain temporal, del bien afectado, o fundado en la falta de ley que la autorice o en la no concurrencia de la causa legal invocada en el acto expropiatorio;

b.- Que se disponga la expropiación total del bien parcialmente expropiado cuando la parte no afectada del mismo careciere por si sola de significación económica o se hiciere dificil o prácticamente imposible su explotación o aprovechamiento;

c. - Que se disponga la expropiación de otra porción del bien parcialmente expropiado, debidamente individualizada. cuando ésta, por efecto de la expropiación. se encontrare en alguna de las circunstancias antes señaladas, $y$

d.- Que se modifique el acto expropiatorio cuando no se conforme a la ley en lo relativo a la forma y condiciones de pago de la indemnización.

Si la resolución judicial da lugar a la reclamación de la letra a, el acto expropiatorio es dejado de inmediato sin efecto, si da lugar a las reclamaciones de las letras b, c, o d, la entidad expropiante dictará un acto expropiatorio adicional o modificatorio, ello no paraliza el procedimiento de expropiación salvo que el Juez en mérito a los antecedentes del proceso lo ordene expresamente.

Si el acto expropiatorio adicional o modificatorio no se adoptare en el plazo requerido, éste podrá dejarse sin efecto por resolución fundada, y para todos los efectos legales la expropiación dejada sin efecto se tendrá por no verificada.

E1 Titulo III del Decreto Ley, artículos 10 al 14, se refieren a la fijación definitiva de la indemnización, el articulo 10 establece que ella se fijará de común acuerdo y a falta de acuerdo por el tribunal competente. El artículo 38 sin embargo, circunscribe el monto de la indemnización al daño patrimonial efectivamente causado con la expropiación y que sea una consecuencia directa e inmediata de la misma. Cabe señalar al respecto, que la Constitución remite la indemnización al daño efectivamente causado, siendo el Decreto Ley en análisis el que agrega que ésta "sea una consecuencia directa e inmediata de la misma".

El Titulo IV reglamenta el pago de la indemnización y sus efectos y se pone ante dos hipótesis diferentes, si existe 
acuerdo rige el articulo 15, a falta de éste rigen los artículos 16 y 17.

Si existe acuerdo, el pago de la indemnización se hará directamente al expropiado, cuando el certificado de hipotecas, gravámenes, prohibiciones y litigios del Conservador de Bienes Raices no tenga constancia de gravámenes y prohibiciones que lo afecten, salvo las servidumbres legales. En la misma circunstancia, se pagará también el monto provisional de la indemnización cuando el expropiado en Escritura Pública se allane a la expropiación y entrega material del bien reservándose el derecho a reclamar del monto de la indemnización.

A falta de acuerdo, si la ley autorizante contempla una forma especial de pago se estará a ella, si no es asi se pagarả al contado y en dinero en efectivo, el que será consignado a la orden del Tribunal. El contenido de la indemnización está dado en dinero, puesto que ellas se hacen con cargo a los presupuestos del Servicio respectivo.

Lo anterior produce una contradicción con los principios y objetivos que fundamentan la ley indigena consistente en, no disminuir las tierras indigenas y propender a su ampliación, y contraviene su estatuto juridico, ya que las tierras afectas a expropiación saldrian del patrimonio indigena por tanto del mercado indigena y ello conlleva una forma de enajenación.

El Gijatum", el Rewe ${ }^{110}$, los Eltum y Cementerios Indigenas, son lugares sagrados para la cultura mapuche, por lo que ellos no son trasladables, ni apreciables en dinero, y si bien tienen una valoración religiosa espiritual inmaterial, dentro de la cosmovisión mapuche están unidos al territorio material mismo.

De tal forma que aceptada como supuesto una ley de expropiabilidad que autorice la expropiación de tierras indigenas, al pretender aplicar para el procedimiento del Decreto Ley 2168. se encuentra una serie de contradicciones con la ley 19.253 .

La Aplicación de esta Normativa en dos casos paradigmáticos: EI Proyecto de Regadío Faja Maisan y la Carretera de la Costa en la IX Región"

En estas dos obras, el Ministerio de Obras Públicas aplicando la normativa analizada en el titulo anterior, esto es, la Constitución Politica de la República, el Decreto con Fuerza de Ley 850 y el decreto Ley 2186 , ha expropiado terrenos indigenas $\sin$ referencia alguna a la Ley 19.253 , la que a la fecha de efectuarse las expropiaciones ya estaba vigente.

Lo anterior, da lugar a la acusación constitucional promovida en contra del ex Ministro de Obras Públicas, señor Ricardo Lagos Escobar, fundada en el artículo $48 \mathrm{~N}^{\circ} 2$ letra b) de la Constitución Política de la República.

Los antecedentes generales y de hecho que expone la Acusación Constitucional en estudio, hacen presente, en primer lugar que, "el Ministerio de Obras Públicas ha procedido a la expropiación de franjas de terreno de diversas propiedades rurales de la Novena Región. con el propósito de construir el Proyecto de Regadio Faja Maisán. Canal Matriz, votras ubicadas en las comunas de Carahue y Teodoro Schmidt, con el fin de construir la Carretera de la Costa en el tramo que une las localidades de Tirúa y Tranapuente".

En la ejecución de los actos conducentes a la expropiación se ha actuado en detrimento de los derechos constitucionales y legales de los afectados, procediendo el Ministerio de Obras Públicas a infringir gravemente la Constitución Politica del Estado, el Decreto Ley 2186 y la Ley 19.253.

Los afectados, pequeños propietarios agricola, de precaria situación socioeconómica y varios pertenecientes, además, al pueblo mapuche, aún no han recibido la correspondiente indemnización a pesar de que el Estado, a través del Ministerio de Obras Públicas, ya tomó posesión material de los terrenos.

"El Ministerio de Obras Públicas no ha efectuado ningin tramite ante la Corporación Nacional de Desarrollo Indigena-CONADI-para cumplir con los requisitos que la Lev 19.253 impone para la permuta de las tierras indigenas. Peor ain, las obras alli ejecutadas han afectado los terrenos donde se encuentra ubicado el cementerio indigena "Eputraguén", sector de Huallisadas, comuna de Pitrufquén. Alli se han realizado excavaciones no autorizadas por la CONADI ni por la Comunidad Indigena respectiva que. en la práctica. han resultado en la profanación de varias tumbas y en la destrucción de un lugar sagrado para la etnia mapuche $y$ de indudable interes de preservación desde el punto de vista cientifico antropológico".

Respecto de la infracción constitucional la acusación señala que, "la posesion material de los bienes inmuebles expropiados ha antecedido al pago total de las indemnizaciones compensatorias, como queda de manifiesto por el estado de adelanto en que se encuentran las ohras viales $y$ de regadio involucradas, que es de público conocimiento, sin que hasta ahora - como por lo demas lo ha reconocido públicamente la autoridad politica - se hava realizado el pago total de las indemnizaciones correspondientes".

Al proceder como se ha descrito, la autoridad politico administrativa se ha colocado al margen de lo dispuesto por la Constitución, infringiendo, a más del artículo $19 \mathrm{~N}^{\circ} 24$ inciso $5^{\circ}$, los principios de supremacía constitucional y de legalidad consagrados en nuestro texto fundamental en los artículos 6 inciso $1^{\circ} \mathrm{y}$ artículo 7 inciso $2^{\circ}$ respectivamente.

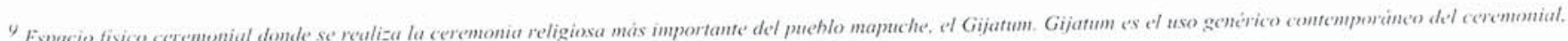

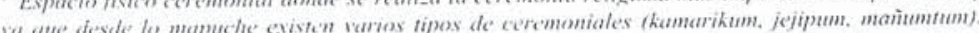

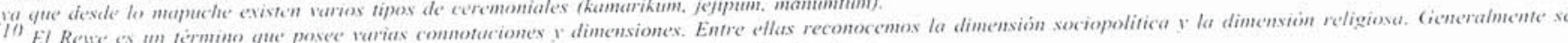

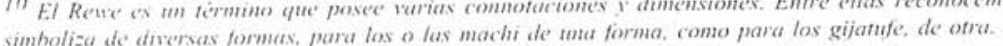

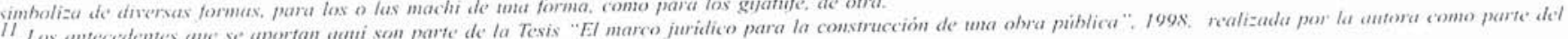
plan curritular de la Fiscuela de Derecho de la Uimsersidad Católica de Temuco.
} 
La infracción de ley de que se acusa a la ex autoridad política del Ministerio de Obras Públicas, es haber "infringido el Decreto Ley 2186, particularmente las disposiciones de sus titulos $I V$ y V que regulan el pago de las indemnizaciones, y la Ley 19253, dado que entre las propiedades expropiadas se encuentran tierras indigenas afectas a la legislación especial sobre pueblos indigenas, respecto de las cuales ni siquiera cabe la indemnización y sólo procede a su respecto una permuta especial, puesto que una ley de carácter general, como el Decreto Ley 2186, bajo ningún pretexto puede dejar sin efecto una ley de carácter especial como es la Ley 19.253".

"Entre los terrenos afectados se encuentra el cementerio indigena "Eputraguén" que fue eliminado por una simple decisión administrativa, lo que constituye una contravención al articulo 19 de la ley 19.253, siendo la comunidad indigena titular de un derecho de reclamación ante los Tribunales a fin de que se restablezca el imperio del derecho. cuestión que en este caso se ve dificultada por el hecho de que el cementerio simplemente ya no existe, puesto que fue arrasado".

Señala finalmente que con esta actuación, "se está estableciendo un peligroso precedente que potencialmente puede afectar a numerosas persona, al dejar incumplidos preceptos constitucionales y legales que garantizan derechos fundamentales de las personas".

La contestación al libelo de acusación constitucional, en lo referente al artículo $19 \mathrm{~N}^{\circ} 24$, inciso quinto de la Constitución Política, señala que, "los afectados por las expropiaciones, tanto en el caso del canal de regadio como en la construcción de la carretera, autorizaron inicialmente, en forma voluntaria y de manera previa y expresa, el uso material de los terrenos para la construcción de las obras respectivas. Ambas autorizaciones, en forma más explicita en el caso de la Carretera de la Costa, fueron el amplio alcance y todo ello, "mientras se realizan los trámites de expropiación".

Referente a la infracción a los Títulos IV y V del Decreto ley $\mathrm{N}^{\circ} 2.186$, manifiesta que, "se ha cumplido estrictamente con todo lo señalado y reitera que el inicio de las obras al amparo de una autorización para el uso material de los terrenos, dada en forma voluntaria y previa, no ha constituido una etapa del proceso expropiatorio propiamente tal".

En cuanto a la infracción a la ley $\mathrm{N}^{\circ} 19.253$, reitera ya lo señalado: "la "autorización de uso material de sus predios" es una acto previo, voluntario y expreso, no inscrito dentro del proceso de expropiación que se inscribe dentro del principio de la autonomía de la voluntad. Pretenderlo limitar, importaria desconocer una de las facultades del dominio, como es la de uso y disposición del bien respectivo, lo que nuestro ordenamiento fundamental no permite, sino por ley, precisamente por respeto o en homenaje al derecho de propiedad".

"Las normas especiales sobre enajenación. gravámenes y permutas que contiene al articulo 13 de la Ley $N^{\circ} 19.253$, no excluyen en absoluto la aplicabilidad de las normas constitucionales que facultan al Estado para expropiar por causa de utilidad pública o de interés nacional. debido a que aquellas son normas de rango simplemente legal y como tales no puede suspender ni tener preeminencia sobre de los preceptos constitucionales".

El pretendido conflicto de normas que se consigna en el libelo acusatorio, entre la Ley Orgánica de Procedimiento de Expropiaciones y la Ley Indigena $\mathrm{N}^{\circ} 19.253$, que es ley común, y que en virtud del principio de la especialidad los acusadores postulan resolver reconociendo primacia a ésta última, no es tal, pues por tratarse de fuentes legales de distinta jerarquia incuestionablemente prima la de mayor rango : la Constitución y su ley de desarrollo, es decir, la Ley Orgánica de Procedimiento de Expropiaciones.

Respecto al cementerio indigena Eputraguén, (...) no es efectivo que se hayan tipificado infracciones a la Ley Indigena (...), el hallazgo de osamentas humanas y elementos culturales en un predio en vías de expropiación, aledaño al canal de regadio Faja Maisán, quedaron al descubierto accidentalmente como consecuencia de las obras que se construian en el sector.

En conclusión, respecto de la ley indigena argumenta que "ésta no sólo no se ha infringido, sino que se ha cumplido escrupulosamente ya que me asiste la convicción de lo valioso que es la cultura indigena y su régimen de tenencia de la tierra. De este modo, siendo el instituto de la expropiación una potestad del Estado, revestida de garantias y de fuente constitucional, lo único que se ha hecho por parte del Ministerio de Obras Públicas es ejercer dicha potestad, al amparo de la ley y con sujeción a la Ley Orgánica de Procedimiento de Expropiaciones. En la medida de lo posible los proceso expropiatorios concernientes a tierras indigenas han tratado de respetar el modus vivendi, cultura y espacio del propietario indigena. Sin embargo, no cabe inexpropiabilidad de las tierras indigenas afincadas en la Ley $N^{\prime \prime} 19.253$, ya que la potestad expropiatoria tiene fuente constitucional y es el constituyente el ínico que le puede fijar limitaciones, que no sean las propias garantias constitucionales, las que no están en cuestión en este punto. Incluso más, el constituyente instituyó un contencioso administrativo especial de anulación del acto expropiatorio por ilegalidad y un contencioso de reparación para disputar el monto de la indemnización, como garantias procesales para defender al expropiado frente a la potestad estatal. Agrega que los expropiados en el caso sub lite no han recurrido a estas garantias procesales, ya que el proceso expropiatorio se ha ajustado a la ley y a la Constitución". 
El informe de la Comisión encargada de estudiar la procedencia de la Acusación Constitucional, en voto dividido -tres a favor, uno en contra y una abstención-, emite una recomendación para, desestimar en todas sus partes el libelo acusatorio por "no ser los hechos imputados constitutivos de delito, infracción o abuso de poder, encuadrables en los ilícitos de infracción de la "Constitución o las leyes" previstos en la letra b), $N^{\circ} 2$ del artículo 48 de la Constitución Politica de la Repuiblica", "12 la que fue acogida en el mismo sentido por la Cámara.

Las argumentaciones para desestimar la acusación, consignan lo siguiente:

"La acusación señala que las tierras indigenas comprendidas por la expropiación se encuentran protegidas "por la legislación sobre los pueblos indigenas respecto de las cuales no procede indemnización sino una permuta especial". También se habría infringido la citada ley con la construcción de obras que afectarian un cementerio indigena (Eputraguén) en el sector de Huallisadas, comuna de Pitrufquén, todo sin autorización ni de la Corporación Nacional de Desarrollo Indigena ni de la comunidad indigena respectiva. El libelo acusatorio sostiene que producida una colisión o conflicto de normas de igual jerarquía corresponde aplicar la ley "de carácter especial" por encima de una ley de carácter general".

"La contestación contra argumenta que no se han infringido los articulos 13, 19 y 29 de la ley $N^{\circ}$ 19.253, ya que las denominadas tierras indigenas, si bien está limitada su enajenación por actos y contratos entre particulares, si son expropiables. Agrega que también caben respecto de ellas actos preparatorios, como en la especie "la autorización de uso material", como lo señala el artículo 13 de la citada ley. Para la contestación del libelo tampoco es atendible la infracción de ley al afectarse un cementerio indigena, que conforme a la ley $N^{\circ} 17.288$, no goza de protección $y$ tuición estatal, por no tratarse monumento nacional. Más aún, practicados los peritajes a osamentas y elementos culturales, se concluyó de que no se trataba de un cementerio indigena o sitio sagrado ceremonial".

Para tomar una decisión respecto del asunto en cuestión, "Estima imperioso definir la naturaleza de la acusación en juicio politico, estableciendo que la acusación es un procedimiento cuva finalidad es perseguir la responsabilidad juridica o constitucional de los funcionarios y magistrados que prevé de modo taxativo el articulo $48 N^{\circ} 2$ de la ley Fundamental, por delitos, infracciones y abusos de poder señalados en la Constitución. Se trata responsabilidad cons- titucional de tipo subjetivo, y no objetivo, y por actos propios y no por actos ajenos o de terceros".

En la ponderación de los antecedentes, "llama poderosamente la atención de la Comisión la circunstancia de que las obras públicas que motivan los procesos expropiatorios referidos en el libelo, no se conoce que hayan sido objeto de impugnación por via judicial o administrativa". Desprendiendo de ello la siguiente conclusión : "Si hubiese merecido algin reparo de ilegalidad el proceso expropiatorio en el "Proyecto de Regadio Faja Maisán" y "Carretera de la Costa", los propietarios afectados habrian recurrido a estos remedios procesales de fuente constitucional, lo que , no ha sucedido".

"En la especie se ha podido establecer que el libelo acusatorio adolece de una debilidad procesal intrinseca, que es la relativa al principio de determinación (...). En efecto, el libelo acusatorio no da cuenta en la relación de sus hechos de un nexo entre éstos e infracciones a la Constitución y a las leyes imputables a actos emanados del ex Ministro de Obras Públicas, y más aún no existe un nexo entre tales hechos y capitulos acusatorios posibles de circunscribir para ser votados como tales".

"En cuanto a los hechos en que sustenta el libelo acusatorio, éstos no conciernen al proceso expropiatorio en si sino a actos voluntarios previos y expresos como la autorización de "uso material de los predios".

"Lo anterior hace convincente estimar que el libelo acusatorio incurre en el yerro de confundir actos preparatorios de naturaleza convencional con actos formales de derecho público insertos en el proceso expropiatorio mismo, lo que vemos reflejado en el documento ya que no basta con efectuar trabajos preparatorios para que se entienda toma de posesión material".

"Referente a la ley $N^{\circ} 19.253$ señala que las denominadas "tierras indigenas", si bien están sometidas a un régimen de tendencia especial y la cultura indigena, valiosa de por si, entregada a la protección del Estado, no es menos cierto que dichas tierras no pueden quedar sustraidas a la potestad expropiatoria del estado. Asi, la prohibición relativa de la enajenación de tierras indigenas, no alcanza al instituto de la expropiación, y no obsta a que propietarios indigenas puedan entregar; todo o parte de sus predios a terceros en comodato, uso, goce o administración, como lo dispone de modo expreso el recordado articulo 13 de la Ley Indigena. En este orden de ideas, la "autorización de uso material de los predios", otorgadas por propietarios indigenas al Ministerio de Obras Públicas tiene cobertura de legitimidad en la Ley Indigena y en el decreto ley $N^{\circ} 2.186$, de 1978".

12 El tenor del dictámen da cuenta del hecho de que no se entró a discutir el fondo de la aplicabilidad o inaplicabilidad de la expropiación a tierras indigenas. lo que se considero un aspecto menor en el contexto de la acusación. la que fue desechada por una cuestión más bien de forma. 


\begin{abstract}
"En cuanto a la protección que la Ley Indigena le confiere a "sitios sagrados ceremoniales" $y$ "cementerios". ésta no se verifica en el caso referido en el libelo acusatorio como cementerio indigena "Eputraguén", situado en la comuna de Pitrufquén, ya que de los antecedentes proporcionados no se acredita que éste sea un cementerio indigena, y menos aín que cuente con declaración de monumento nacional según lo prescrito en la ley $N^{\circ} 17.288$. Por lo demás, el fortuito hallazgo de osamentas y elementos de contenido cultural, en un lugar no demarcado e ignorado por todos, incluso por el poseedor del terreno, no es de responsabilidad del ex Ministro imputado".
\end{abstract}

\section{Los Criterios y Paradigmas para la Interpretación}

Existe una contradicción entre normas jurídicas cuando dos normas imputan al mismo caso soluciones incompatibles. Para resolver tales contradicciones la doctrina jurídica ha creado los llamados criterios de interpretación cronológico, jerárquico y de la especialidad.

El criterio cronológico dice que la ley posterior prima sobre la anterior, requiere para su aplicación la mera comprobación del hecho de la promulgación de las leyes en conflicto y la fecha correspondiente.

El criterio jerárquico señala que la ley superior prevalece sobre la inferior. Para su aplicación hay que atenerse a la estructura jerárquica del orden jurídico que tiene su fuente y norma de primer orden en la Constitución.

El criterio de la especialidad expresa que la ley que regula en especial una materia determinada prevalece sobre una ley de aplicación general. Su aplicación requiere un juicio de hecho sobre la distinta extensión de las disposiciones normativas, tanto respecto de la validez material como personal de las normas y se entiende fundamentado en la aplicación del principio de justicia según el cual deben ser tratadas de igual modo las personas que pertenecen a la misma categoría.

Del análisis de la Ley 19.253 y el Decreto con Fuerza de Ley 850 , se evidencia que existe una contradicción normativa ya que el decreto declara que todas las tierras necesarias para la construcción de caminos son de utilidad pública, y la Ley 19.253 declara las tierras indigenas protegidas por el interés nacional sobre la base del cual prohibe la enajenación, el embargo, los gravámenes y la prescripción adquisitiva salvo entre indigenas de una misma etnia.

Ante tal contradicción en virtud de los principio de especialidad y de jerarquía normativa, la Ley 19.253 prima por el Decreto con Fuerza de Ley 850, el que no es aplicable a la expropiación para la construcción de obras públicas en tierras indigenas.
El Decreto Ley 2186, presenta una serie de contradicciones con la Ley 19.253. Al respecto, una ley posterior deroga o prevalece sobre, según el caso, una ley anterior, por lo que este criterio por si solo no nos permitiría descartar su aplicación. El principio de la especialidad llevaría a la misma conclusión, ya que esta nueva ley estará rigiendo para una materia específica determinada y mas estrecha que el ámbito completo de expropiaciones. El criterio de la jerarquia normativa confirma la especialidad pues el artículo 13 que establece el estatuto juridico de las tierras indigenas y el articulo 17 que establece la indivisibilidad de las mismas, son artículos de quórum calificado y un Decreto con Fuerza de Ley tiene en nuestro ordenamiento una menor jerarquía normativa.

Desde un punto de vista de interpretación jurídica se puede concluir que, ante las contradicciones normativas existentes entre el Decreto Ley 2186, el Decreto con Fuerza de Ley 850 y la Ley 19.253, ésta prevalece sobre los anteriores por constituir norma especial con relación a los indigenas y las tierras indigenas.

La expropiación es una institución de derecho público, su principio rector es la competencia. Toda vez que la Ley 19.253 es especial con relación al Decreto Ley 2186 y al Decreto con Fuerza de Ley 850 , ella que no existe para la expropiación de tierras indigenas, es más, la administración está obligada por la ley 19.253 artículo $1^{\circ}$ a: "Respetar; proteger y promover; las tierras indigenas, velar por su adecuada explotación, por su equilibrio ecológico y propender a su ampliación ", la argumentación señalada impide la aplicación del procedimiento de expropiaciones en tierras indigenas.

Lo anterior en atención a una interpretación de acuerdo a los principios creados y utilizados para estos efectos por la doctrina jurídica, sin embargo el trasfondo cultural que involucra la interpretación de la relación hombre-tierra, para los mapuche (gente de la tierra), ni siquiera es vislumbrado en toda esta interpretación.

Desde el punto de vista de la cosmovisión indigena, existen otros argumentos que sustentan la inaplicabilidad del decreto ley 2186 y el Decreto con Fuerza de Ley 850 a las tierras indigenas regidas por la Ley 19.253, los que se relacionan más bien con la necesidad de aceptar la diversidad ${ }^{\prime 3}$, de ahi que creemos que las argumentaciones cuando se traten temas con contenido étnico deben necesariamente incorporar variables de tipo político cultural insertas en la cosmovisón del pueblo de que se trate.

Con la dictación de la actual ley indígena, hubo un intento de introducir al ordenamiento jurídico chileno un cambio sustantivo en los paradigmas de la relación Estado/ Pueblos Indigenas, el que sin embargo desaparece a través de una interpretación exegética sustentada en paradigmas que no consideran la cosmovisión del otro, circunscribiendo el problema indigena solamente a un problema económico y de clases que

\footnotetext{
13 Esta falta de espacio para la diversidad incide y es también aplicahle a la solución juridica que en la práctica judicial se da a otro tipo de situaciones que conllevan un contenido itnico, asi por ejemplo a los casos expuestos por los abogados Jaime López y Rodrigo Lillo en sus respectivos trabajos y que forman parte de la presente puhlicucion.
} 
por lo demás afecta sólo a determinadas comunidades. En la misma lógica se razona que se solucionaría con más y mejores tierras, más educación, más tecnología, etc. todo ello considerado desde la apreciación de lo que es más y de lo que es mejor desde el punto de vista de la cultura occidental dominante.

La perspectiva correcta para la apreciación del límite de la protección de las tierras indígenas y junto con ello la respuesta a la expropiabilidad o inexpropiabilidad de las mismas, exige un cambio real de los paradigmas de sustentación de la relación Estado/ Pueblos Indigenas.

Si se acepta que Chile es un Estado multicultural y multiétnico, los argumentos de fondo para la inexpropiabilidad de las tierras indígenas y la inaplicabilidad de los ordenamientos legislativos que en la actualidad rigen la materia de las expropiaciones, evidentemente estarán relacionados con los aspectos culturales de la diversidad y en este contexto son los siguientes:

1. - La tierra tiene para los mapuche un valor cultural que la expropiación afectaria en esencia.

El concepto de propiedad sobre la tierra reviste características particulares para el pueblo mapuche, la concepción central en su cosmovisión es la unicidad del hombre y la naturaleza, lo que la hace diferente de la cultura no indigena mayoritaria en nuestro pais, la que realiza una drástica separación entre lo social y lo natural.

Para el wigka ${ }^{14}$ la tierra tiene sólo un valor de cambio, objeto de transacciones, para el mapuche tiene un valor de uso de carácter colectivo, es el espacio físico en el que se desenvuelve la vida cultural y se desarrolla la identidad, esta particular cosmovisión, considera sagrados los cementerios donde reposan sus antepasados, los espacios sociales ancestrales, rituales y religiosos, los que están cargados del sentido cultural de la etnia especifica y de la comunidad de que se trata.

La actual ley indigena, reconoce que para los mapuche la tierra es el fundamento de su existencia y su cultura.

Tanto el Gijatum, como el Rewe, los Eltum y cementerios indigenas, son lugares sagrados para la cultura mapuche, ellos a diferencia de lo que ocurre en el mundo no indígena, no son trasladables, pues estos lugares constituyen un espacio inmaterial que dentro de la cosmovisión mapuche están unidos al territorio material mismo.

La afectación del territorio así considerado a través del procedimiento de expropiaciones, atentaría en esencia contra el derecho a la cultura y sus manifestaciones de parte de los indígenas, lo que está prohibido por el artículo $19 \mathrm{~N}^{\circ} 26$ de la
Constitución, cabe recordar además que el artículo $5^{\circ}$ de la Carta Fundamental establece como límite a la soberania el respeto a los derechos humanos.

Desde esta perspectiva, aún cuando el trazado de una obra pública, no pase directamente sobre la manifestación material de un Rewe, el sólo hecho de atravesar el territorio que forma parte de su fütalmapu ${ }^{15}$ igualmente está afectando la unidad social, política y el desarrollo de la convivencia natural. esto es, el valor cultural de las tierras indígenas.

La construcción de una determinada obra, depende de una acción material del hombre sobre la naturaleza lo que le permite construirla sobre un lugar libremente elegido, pudiendo alterar su trazado si ello es necesario. Sin embargo un $\mathrm{Ce}$ menterio Indigena, un Rewe, un Gijatum, que ya existen al interior de las comunidades desde tiempos inmemoriales, no pueden trasladarse porque son espacios sagrados para la cosmovisión indigena mapuche.

2. - La Ley 19.253 otorga a los indigenas derechos de ejercicio colectivos sobre el territorio, el ejercicio de la cultura que les es propia y el derecho a la participación. la aplicación del DL 2186 y DFL 850 hacen irrealizables tales derechos.

Durante la tramitación de la actual ley indigena 19.253, el legislador tuvo presente los derechos colectivos de los indigenas, al respecto se señaló "(...) hay grupos, una cultura y una etnia que poseen los mismos derechos, la misma jerarquia y dignidad que las otras culturas; que gozan de derechos consustanciales, que son derechos humanos inherentes a la esencia del hombre, que brotan directamente de él por el solo hecho de ser hombre, como exigencias necesarias de su intrinseca dignidad de ser espiritual; y que dentro de esta categoria de derechos humanos existe una tercera categoria que se ha llamado "derechos humanos colectivos o de tercera generación", constituido por el reconocimiento a la identidad cultural del pueblo del cual se forma parte y que implica su mantenimiento y enriquecimiento, donde el sujeto ya no es el ser individual sino el pueblo o grupo étnico del cual es parte (...)". Diputado Ojeda. (Historia de la Ley 19.253, pp. 3729).

Se discutió también la inserción de los indigenas, como organismos intermedios de los reconocidos en el artículo $1^{\circ}$ de la Constitución, punto sobre el que se señaló lo siguiente: " Al discutir la presente iniciativa y recordar que el Estado protege y ampara a los grupos intermedios de la sociedad. me gustaria entender que esta expresión de la Carta la estamos extendiendo, no solamente a esos grupos en cuanto a la organización administrativa de la sociedad, sino, también a la expresión social o natural de los hombres que habitan este territorio, es decir; a sus etnias". Senador Cantuarias. (op. cit.pp. 1572).

\footnotetext{
14 El no indigena. mirado desde la cosmovisiön del pueblo indigena.

15 Ambito de jurisdicción de un rewe
} 
"El inciso tercero del articulo 1" de la Carta Fundamental los considera como grupos intermedios; en cuanto representan una realidad sociológica que es diferente de la persona de sus miembros y de la sociedad organizada en el Estado (...)". Diputado Ojeda. (op. cit. 3730).

Sobre la base de estas argumentaciones, se reconoce a las etnias indigenas de Chile, se valora su existencia por ser parte esencial de las raíces de la Nación Chilena, especificándose además el reconocimiento y valoración de su integridad y desarrollo de acuerdo a sus costumbres y valores, así lo entendió el legislador, existiendo constancia en las actas de la discusión de la ley, "Tenemos que respetar las organizaciones originarias de los indigenas, y también las que ellos han creado en el transcurso de los años como instituciones, que son reales, por tratarse de organismos intermedios entre el hombre y el Estado ". Senador Diez.(Historia. Op. Cit. Pp 1495).

Para establecer los derechos colectivos de los indigenas en Chile, el legislador tuvo presente experiencias anteriores en que existiendo un reconocimiento legal dentro de una ley especial a los derechos de los indígenas de carácter individual, éstos no fueron respetados desde una perspectiva de derechos colectivos ya que no estaban expresamente reconocidos.

Específicamente se señaló que, "No basta proclamar y proteger los derechos individuales de tipo universal. La negación de los derechos colectivos de los pueblos autóctonos ha conducido muchas veces a violaciones masivas de sus derechos individuales básicos". Senador Navarrete. (Historia. Op. Cit. Pp 1479).

El respeto a los derechos de los indígenas en nuestro país no se circunscribe sólo a los indigenas individualmente considerados, las comunidades y las asociaciones indigenas definidas en la propia ley, se extiende a la titularidad de derechos colectivos de parte de las etnias indigenas en su conjunto, existiendo en ello una íntima vinculación con la protección del territorio indigena dado que la ley reconoce que "para ellos la tierra es el fundamento principal de su existencia y cultura".

Los derechos colectivos de los indígenas en Chile están contenidos en los artículos 7, 19 inciso $1^{\circ}$ y 34 de la ley 19.253. Estos son los el derecho a la cultura, a la representación y a la participación.

Habiendo el Estado de Chile reconocido a las etnias indigenas estos derechos de carácter colectivo, tiene el deber de respetarlos y como contrapartida el pueblo mapuche tiene legítimo derecho a su ejercicio, ello involucra participar en la preservación, revitalización y construcción de una identidad colectiva.

${ }^{16}$ El subrayado es de la autora.
Hacer uso del derecho a participar en la toma de decisiones, involucra una actitud activa del mundo indigena y sus organizaciones.

Estando claramente establecido que los indigenas tienen pleno derecho a la participación en cualquier tipo de materia que los afecte, cabría señalar que no se trata sólo de una participación formal en cuanto a los resultados de la ejecución de un proyecto que afecte sus tierras o del impacto que éste produce sobre ellas, sino respecto de la misma inexistencia dentro del ordenamiento juridico nacional de una competencia legal sobre la que la administración del Estado sustenta su competencia para la expropiación de las tierras indigenas.

3. - La fundamentación de la protección de las tierras indigenas en la discusión de la ley, los principios básicos en ella establecidos, y el estatuto especial que rige las tierras indigenas, hacen incongruente la pretensión de declarar su expropiación.

La historia de la discusión de la ley es clara al señalar que la protección de estas tierras obedece a un imperativo jurídico que involucra a la nación toda.

Los principios de la Ley 19.253 son claros al señalar como un deber del Estado y sus instituciones "proteger las tierras indigenas, velar por su adecuada explotación, por su equilibrio ecológico y propender a su ampliación " $"$.

La normativa especial indígena declara la protección de las tierras indígenas, prohibiendo su enajenación en sentido amplio, circuncribiéndolas al mercado especial de tierras indígenas todo ello por exigirlo el interés nacional, no existe en nuestro ordenamiento una ley que autorice la expropiación ni una ley que regule el procedimiento de expropiaciones aplicable a tierras indígenas.

\section{La Respuesta desde el Mundo Indígena}

La expropiación de las tierras indigenas para la construcción de obras públicas afecta los derechos fundamentales de los indigenas, ¿porqué éstos no recurren a los Tribunales en demanda de la efectiva protección de sus derechos?. La respuesta a esta interrogante plantea un punto de permanente conflicto en la relación entre el Estado y los pueblos indígenas, que dice relación con la desigualdad de poder para acceder a la justicia, la desconfianza y la conciencia existente en el mundo indigena actual de la total falta de comprensión de gran parte de la sociedad chilena respecto de su distinta forma de vida, cultura y cosmovisión.

Todo el sistema lógico dialéctico de la Legislación Chilena, así como su ejercicio, obedece a una elaboración cultural occidental, que no da espacio a la interculturalidad y que 
es muy ajeno a la cosmovisión y a la lógica dialéctica de la cultura mapuche.

Si bien es cierto la ley indigena declara la protección de las tierras indigenas en virtud del interés nacional; la aplicación de esta normativa en la práctica judicial no se condice con ello. Como producto de toda esta situación la percepción desde el mundo indigena es que: para los indígenas no existe justicia en Chile toda vez que su diferencia cultural no es considerada.

En este orden de cosas, aparece como peligroso para los indigenas recurrir de inaplicabilidad o nulidad de la expropiación, toda vez que es el mismo Estado el que atropella sus derechos

Si bien el proceso previo a la dictación de la ley indigena implicó la discusión de las relaciones Estado/Pueblos Indígenas, desde una posición de apertura política y aceptación mutua contextualizada en el retorno a la democracia y la efectiva vigencia de los derechos humanos; $y$, en los mismos términos discurrieron las argumentaciones en la discusión de la ley en el Parlamento - en muchas de cuyas sesiones gran parte de la dirigencia indígena de la época estuvo presente -, el articulado definitivo, se enmarcó en los paradigmas y la coherencia interna del Estado chileno y la cultura dominante, esto deja sin poder politico efectivo al movimiento indigena que, en un primer momento no logra visualizar esta situación.

Desde la promulgación de la Ley 19.253 en 1993 y aproximadamente hasta 1997, el movimiento indigena, mayoritaria aunque no totalmente respaldó las políticas generales del Estado Chileno en relación al tratamiento del tema indígena, sin embargo las criticas, discrepancias y cuestionamientos empiezan a aparecer y van paulatinamente en aumento en cuanto la dirigencia indigena empieza a comprender que aún con la dictación de tal ley, desde las esferas gubernamentales se privilegian los intereses de los círculos de poder económico, en perjuicio de los legítimos derechos de los indigenas y sus tierras quedan una vez más en la indefensión.

Crecientemente se desarrollan discursos y prácticas que cuestionan los fundamentos sobre los que se sustentan las relaciones entre el Estado y los pueblos indigenas, señalando que lo que hay tras toda esta situación, es un intento asimilacionista y el enmascaramiento cada vez más refinado de una forma de dominación política.

Existe un sector de la juventud indigena que ha sido capacitada técnica y profesionalmente en diferentes áreas; parte de este grupo - que entre los indigenas se podria llamar privilegiado-, está acercándose a las organizaciones, formando nuevas organizaciones o vinculándose directamente con las co- munidades en conflicto, entendiendo que el problema de cualquier comunidad o indigena individualmente considerado ya no es un problema individual sino un problema de pueblo. En esta perspectiva todo indigena se siente directamente afectado y parte de los conflictos que ocasiona la demanda del territorio, validándose de esta forma como interlocutores de representación de su pueblo, contexto en el cual también son validados por las comunidades en conflicto ${ }^{17}$. Surge asi una nueva generación de dirigentes.

El uso que estos nuevos dirigentes hagan de sus conocimientos, tanto de la cultura occidental como de su propia cultura y su capacidad de negociación será determinante para definir su posición desde el pueblo que representan.

En un extremo esta la posibilidad de que sean absorbidos por la cosmovisión occidental y manipulen su identidad en su propio beneficio pasando a ser indígenas para el Estado y sus instituciones y dejando de serlo para sus hermanos de sangre $^{18}$, en el otro el que se conviertan en una nueva elite de dirigentes con una posición clara respecto a la autoidentidad y a una propuesta de pueblo desde el interior de éste.

La coyuntura sociopolítica actual favorecería esta última alternativa, sin embargo es un proceso que no carece de escollos, quizás el más importante es poder darse cuenta que el problema indigena es y ha sido desde siempre un problema politico centrado en la relación del Estado y sus pueblos originarios.

El despertar de la conciencia étnica del pueblo mapuche, nace como respuesta a una historia de atropellos largamente soportada y se convierte en el agente que permite a los indigenas repensar su historia, reestructurar la cosmovisión y movilizarse en demandas politicas globales, surgiendo como alternativa una posición política de pueblo, que reúne y conjuga los elementos centrales e intransables de la cosmovisión que aún permanecen en la sabiduría de los ancianos ülmenes, con la fuerza el conocimiento y la técnica de la juventud, en el marco de una visón asentada en la propia cosmovisión.

A pesar de las diferencias existente al interior del mundo indígena ${ }^{19}$, hay temas de consenso que bien pueden ser la base de esta nueva relación entre el Estado y los Pueblos Indigenas y que deben necesariamente ser parte de un proceso de negociaciones. Ellos apuntan fundamentalmente al reconocimiento como pueblo, la defensa del territorio y una mayor autonomía, apareciendo como respuesta a una situación largamente sostenida de opresión y desigualdad de poder.

- En el marco de la sociedad contemporánea, los actuales mapuche no se conforman con más dinero, más becas, más capacitación, más tierras, más ..., porque todo ello se enmarca en una actitud paternalista y un criterio economicista de parte de la sociedad occidental, que se niega a reconocer la diversidad cultural, necesitan y demandan su territorio que es

\footnotetext{
17 La categorizaciön de "infiltrados" que desde las esferas de gobierno se aplica a estos dirigentes indigenas por al hecho de provenir del medio urtano o de commidade's distintas a las directamente afectadas por los conflictos en los que actuian. pretende desconocer la existencia de este fenómeno y minimiza las demandas a uta comunidad territorial especifica.

IS Como en opinion de algumos dirigentes de organizaciones indigenas, ya ha sucedido con algunos antiguos dirigentes que se fueron a la actual CON.Al) y que en la actualidad son solo parte de un organismo estatul habiendose alcjado sensiblemente de sus organizaciones.

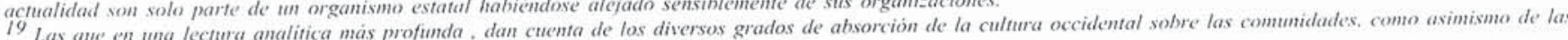
miltiples hertamientas utilizadas durante este proceso.
}

Revista CUHSO - Volumen Especial - 64 
parte de su historia ancestral y una actitud de diálogo y mayor respecto como los pueblos originarios de este pais. ello pasa por respetar su propia cosmovisión y por una mayor autonomia.

El mundo indigena actual exige un espacio real a la multiculturalidad. este es un tema de definición politica de Estado. es en este contexto donde se ubican las actuales demandas de los pueblos indigenas al Estado de Chile y que especificamente se refieren. al reconocimiento constitucional del pueblo mapuche ${ }^{20}$, la ratificacion e integracion al ordenatmiento juridico nacional del convenio 169 de la OIT, el respeto a sus territorios y a sus derechos tanto individuales como colectivos como pueblos originarios de este pais.

\section{CONCIUSIONES}

1.- La protección de las tierras indigenas que, como una exigencia del interés nacional, establece la Ley 19.253. obedece a tres ideas centrales básicas: el reconocimiento de la existencia de las etnias indigenas en el contexto de la sociedad nacional. el reconocimiento de su estrecha relación con la tierra como fundamento de su existencia y cultura y la valoración de las mismas como parte integrante de las raices de la nación Chilena.

2.- La respuesta a la interrogante acerca del límite de la protección a las tierras indigenas, establecido en la Ley 19.253. involucra el análisis de un tema de fondo subyacente en toda la legislación que el Estado ha dictado para los indigenas en Chile. esto es. la no aceptacion de la multiculturalidad y el fracaso del sistemático intento asinalacionista de los pueblos indigenas existentes al interior de la sociedad chilena.

3.- Juridicamente la posibilidad de expropiación de tierras indigenas para la construcción de una obra pública, esta regulada por. la Constitución Politica de la República, el Decreto Ley 2168 de 1978 que autoriza la Ley Organica del Procedimiento de expropiaciones, y el Decreto con Fuerza de Ley 850 del 12 de Septiembre de 1997. Ley Orgánica del Ministerio de Obras Públicas. Concurriendo ademais a su regulación en el caso de las tierras indigenas, . la Ley indigena 19.253 de 1993.

4.- El Estado de Chile a través del Ministerio de Obras Públicas, sostienc que " Las normas especiales solme enajenacion. gravimenes r permutas que contiene al articulo 13 de la Lev N"19.253. no excluyen en absoluto la aplicabilidad de las normas constitucionales que facultan al Estado para expropiar por causa de atilidad puiblica o de interés nacional. debido a que aturellas son normas de rango simplemente legal y comos tales no puede suspender ni tener presmincencia sobre de los preceptos constitucionules". De acuerdo a ello aplica la normativa general de la expropiación en tierras indigenas sin consideración al contenido étnico.

5.- En este trabajo, analizados los cuerpos legales que rigen en general la expropiación en relación a la ley indigena, se detecta la existencia de contradicciones, respecto de las cuales realizada la interpretación juridica según criterios doctrinarios. se concluye que. la Ley 19.253 prevalece sobre los otros cuerpos legales por constituir norma especial con relacion a los indigenas y las tierras indigenas. de tal forma que éstos resultan inaplicables a la expropiación de tierras indigenas

6.- Si se acepta que Chile es un Estado multicultural y multiétnico. existen otros argumentos de fondo para la inexpropiabilidad de las tierras indigenas y la inaplicabilidad de los ordenamientos legislativos que en la actualidad rigen en general la materia de las expropiaciones, los que se fundamentan en los aspectos culturales de la diversidad, y son los siguientes: Fal valor cultural de la tierra dentro de la cosmovisión mapuche. los derechos de ejercicio colectivos sobre el territorio. la fundamentación de la protección de las ticras indigenas en la discusión parlamentaria y los principios básicos establecidos en la Ley 19.253.

7.- La respuesta actual a la constante afectación de su territorio y el desconocimiento de sus derechos, desde el mundo indigena. es el fortalecimiento de la conciencia étnica, en cuyo contexto se desarrollan discursos y prácticas que cuestionan los fundamentos sobre los que se sustenta la relación entre el Estado y los pueblos indigenas en la sociedad Chilena.

8.- Asistimos al surgimiento de una nueva dirigencia indigena. que no se conforma con respuestas parciales, el mundo indigena actual exige un espacio real a la multiculturalidad. este es un tema de definición política de Estado. Es en este contexto donde se ubican las actuales demandas de los pueblos indigenas al Estado de Chile y que especificamente se refieren, al reconocimiento constitucional del pueblo mapuche, la ratificación e integración al ordenamiento juridico nacional del convenio 169 de la OIT. el respeto a sus territorios y a sus derechos tanto individuales como colectivos como pueblos originarios de este pais.

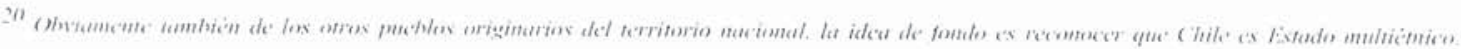




\section{BIBLIOGRAFIA}

- AYLWIN. J. (1994) Pueblos Indigenas de Chile: Antecedentes Históricos y Situación Actual. Serie Documentos $N^{\circ}$ 1, Instituto de Estudios Indigenas, Universidad de la Frontera. Temuco, Chile.

- AYLWIN, J. (1995) Estudio Sobre Tierras Indigenas de la Araucania: Antecedentes Histórico Legislativos (18501920). Serie Documentos $N^{\circ} 3$, Instituto de Estudios Indigenas, Universidad de la Frontera. Temuco, Chile.

- BENGOA, J. (1985) Historia del Pueblo Mapuche (Siglo XIX y XX) Ediciones, Santiago, Chile.

- CONSTITUCION POLITICA DELAREPUBLICA DE 1980. publicada en el Diario Oficial el 24 de Octubre de 1980.

- DECRETO LEY 2.168, que autoriza la Ley Orgánica del Procedimiento de Expropiaciones, publicado en el Diario Oficial el 09 de Junio de 1978.

- DECRETOCON FUERZA DE LEY 850 del 12 de Septiembre de 1997, publicado en el Diario Oficial el 25 de Febrero de 1998

- HISTORIA DE LA LEY 19.253 (1997) Compilación de textos oficiales del debate parlamentario. Biblioteca del Congreso Nacional de Chile. Santiago, Chile,

- LEY 19253. PROTECCIÓN. FOMENTOY DESARROLLO DE LOS PUEBLOS INDIGENAS, publicada en el Diario Oficial el 05 de Octubre de 1993.

- LILLO, R. (1999) "La Legislación como aspecto de la Relación Intercultural", 1999, en este volumen.

- LOPEZ ALLENDES, J. (1999) "Las Tierras Indigenas en la ley 19.253". en este volumen.

- PRECH PIZARRO, J.(1997) Constitucionalidad del Estatuto Juridico de la CONADI en referencia al artículo 19 $N^{1: 23.19} N^{\circ} 24$ y $19 N^{*} 21$ de La Constitución. Informe en Derecho.

- SALAMANCA HUENCHULlan, M. (1998) "El Marco Juridico para la Construcción de una Obra Pública en Ticrras Indigenas". Tesis, malla curricular, $5^{\circ}$ año, para el egreso de la Escuela de Derecho Universidad Católica de Temuco. 